\title{
UIT EN OVER DE MINAHASA.
}

\section{VOORWOORD.}

Samengevat onder dit hoofd, heeft het Bestuur besloten in deze «Bijdragen» achtereenvolgens een zevental artikelen over de Minahasa te doen verschijnen, tot welker samenstelling eenige jaren geleden het initiatief werd genomen door den heer L. Adam, toenmaals Controleur B. B. ter beschikking van den Resident van Manado. Waar eenerzijds Graafland's bekend werk over de Minahasa laatstelijk gedagteekend is van 1898 en anderzijds de Minahasa bij voortduring zich moderniseert, terwijl over sommige oude instellingen, tuestanden enz. sedert nieuw licht is opgegaan, werd de tijd gekomen geacht voor een nieuw werk over land en volk van de Minahasa, beschouwd met betrekking tot de verschillende zijden van het wetenschappelijk en godsdienstig leven door een aantal deskundige schrijvers.

Oorspronkelijk bedoeld als een uitgaaf van het aan het Ned. Ind. Departement van Binnenlandsch Bestuur verbonden Encyclopaedisch Bureau, geschiedt de publicatie thans van wege het Koninklijk Instituut, vermits om verschillende redenen het evengezegd oorspronkelijk denkbeeld is moeten worden prijs gegeven, onder aanteekening voorts dat het ook niet is mogen gelukken om voor alle in aanmerking gebrachte onderwerpen bewerkers naar den eisch bereid te vinden. Ook tot deze bescheiden afmeting teruggebracht, bevat deze reeks Minahasa-artikelen nochtans zooveel waardevolle kennis, dat het Instituutsbestuur gemeend heeft tot de publicatie te moeten overgaan, daarbij de sedert veranderde spelling van sommige aardrijkskundige namen onveranderd latende. 


\title{
I. DE MINAHASSA EN DE GENEESKUNST.
}

DOOR

\author{
A. C. N. BOUVY,
}

Arts, Off. v. Gez. le kl, O. I. L.

I.

Inleiding.

In een werk over de Minahassa, waarin land en volk door de verschillende schrijvers, al naar gelang van hun werkkring, studievak en levensopvatting door verschillend gekleurde bril zal worden bekeken, mag het geneeskundig deel niet ontbreken.

In de bestaande werken over de Minahassa is dit gedeelte zeer stiefmoederlijk behandeld.

In het standaardwerk van N. Graafland, laatste uitgave van 1898, een hoogst verdienstelijke arbeid overigens, beslaan de geneeskundige aangelegenheden luttele bladzijden. Na vier jaar werkzaam te zijn geweest als geneesheer in dit schoone land, zal ik in de volgende bladzijden trachten weer te geven wat gedaan werd, en behoort gedaan te worden voor de gezondheid van dit volk. Vanzelf zal dan ook voor den dag komen, hoe mijn totaal indruk van land en volk is en dan ontveins ik mij niet, dat deze in vele opzichten anders zal luiden dan van vroegere schrijvers. Het is ook elders mijne ervaring geweest dat zielverzorgers de menschen veelal niet in hunne gewone doen aantreffen - bij een bezoek van een predikant of bij een gewone visite ziet men den mensch "op zijn Zondags».

De geneesheer ziet den mensch dikwijls, ook figuurlijk, in al zijne naaktheid.

Bij zieken, die zich in gevaar achten vooral, is alle houvast van aangeleerd fraais, paaschbeste kleeren enz. verdwenen.

Uit beide beschouwingen kan dan «le juste milieu» worden geboren. Bij de behandeling van de lichaams- en geestes-eigenschappen van den Minahasser zal ik gelegenheid hebben daarover mij verder uit te spreken. 
II.

Eerste geneeskundigen.

De eerste geneesheer, die in de Minahassa kwam zal wel een Officier van Gezondheid geweest zijn, behoorende bij de Militaire nederzetting in het Fort te Menado. Waar het Fort in de vorige eeuw nog aan aanvallen bloot stond, is pas in de tweede helft van die eeuw sprake van op meer uitgebreiden voet verleenen van geneeskundige hulp. Bij de instelling van [Doktersdjawa komen ook spoedig deze in de Minahassa. In 1902 komt de Burgerlijke zieken-inrichting te Menado tot stand.

\section{Vaccinatie.}

In het begin van de twintigste eeuw waren nog 12 Doktersdjawa werkzaam in de Minahassa. Vóór 1908 werd nog veelal gevaccineerd van mensch op mensch. In 1908 wordt de inenting met animale vaccine ingevoerd en de werkzaamheid der vaccinateurs beter, systematischer geregeld. Terwijl vóór 1908 elk jaar een epidemie van pokken voorkomt, is dit na 1910 afgeloopen.

Vinden we vóór 1908 elk jaar getallen van $20-200$ pokkengevallen en meer, van af het oogenblik van systematisch vaccineeren der bevolking is dit gedaan. In 1911 geen enkel geval meer en zoo gaat dit door tot 1916, in welk jaar een kleine epidemie, tot één kampong beperkt, mij levendig voor den geest staat. In enkele dagen hebben wij toen 10.000 personen ingeënt, als het ware de haard omgeven van een "wal» van pas gerevaccineerden. Slechts één geval deed zich daar buiten voor, mijlen er vandaan, midden in het bosch bij een eenzamen ouden man, die nooit gevaccineerd was.

Tegenstanders van de vaccinatie zal men in Indië, en zeker in de buitenbezittingen, niet gemakkelijk aantreffen. In Holland zijn dezen veelvuldiger, omdat men daar de ziekte, practisch gesproken, niet meer kent. Natuurlijk ging dit invoeren der vaccinatie met koepokstof geleidelijk. Eerst in September 1910 wordt overal in de Minahassa uitsluitend met koepokstof ingeènt. Teekenend is ook, dat, terwijl in 1909 in de Minahassa zich bij een epidemie 144 gevallen van pokken voordeden, in het aangrenzende Bolaäng-Mongondow, dat slecht gevaccineerd was, 7.800 gevallen voorkwamen. 
'Het nazien der rapporten uit die jaren is een nekslag voor het vooroordeel tegen vaccinatie.

Duizenden menschenlevens zijn in de Minahassa gespaard gebleven na 1910, dat is een ieder, die wil begrijpen, duidelijk.

Wat hebben dan tenslotte enkele nadeelige gevolgen in enkele gevallen te beteekenen? Ik zag bij de tienduizenden vaccinaties, die ik verrichtte, nog nooit één sterfgeval aan de inenting te wijten. Wel zag ik nu en dan een heftige reactie of een uitslag.

Ik weet voorts, dat nu en dan een sterfgeval op rekening der vaccinatie wordt geboekt. Maar welk redelijk mensch zal daarom een kunstgreep afkeuren, die zooveel zegen gebracht heeft?

Elke operatie, elk medicament, dat specifiek werkt, kan nadeelige gevolgen of sterfgevallen met zich medesleepen. Zal men daarom geen buikoperatie meer doen of geen kwikpraeparaten, of chinine, of cokaine, of chloroform meer gebruiken?

Men kan gerust zeggen, dat de vaccinatie veel minder schadelijk is, dan een der genoemde handelingen.

III.

Burgerlijke Geneeskundige Dienst.

Beschouwen wij nu den toestand, zooals deze tegenwoordig is, dat wil zeggen: Welke geneeskundige hulp wordt der bevolking op heden geboden en in welken vorm?

In de eerste plaats is dan te Menado sinds menschenheugenis, als eenig Europeesch geneesheer, geplaatst een Officier van Gezondheid, die gemiddeld drie jaren ter plaatse vertoeft om dan te worden overgeplaatst.

Deze termijn van drie jaar mag, zelfs voor de plaatsing van een Officier van Gezondheid, vrij lang worden genoemd.

Hoewet de werkkring eene aangename is, zullen de meesten het na verloop van dien tijd niet hebben betreurd een zoo klein provinciaal plaatsje als Menado te hebben moeten verlaten. Echter kan een geneesheer, die langer op een plaats gevestigd blijft, meer tot stand brengen. Voor geneesheeren geldt al het zelfde als voor bestuursambtenaren: te snelle wisseling werkt het tot stand komen van verbeteringen niet in de hand.

$\mathrm{Nu}$ behoeft men zich niet al te zeer te verwonderen, dat de meeste Officieren van Gezondheid niet veel konden doen voor dit land op sociaal geneeskundig gebied. 
In de eerste plaats ontbrak hun daartoe de tijd, in de tweede plaats de gelegenheid en ten slotte veelal de lust.

Het eenige, wat zij ten volle konden doen, en ook deden, was hun persoon geven aan de zaak, de zieken zooveel mogelijk thuis bezoeken en zich voor het geven van raad beschikbaar stellen op hunne poliklinieken.

Dagelijks houdt de geneesheer polikliniek van 10 tot 1 uur in het Fort. Dagelijks worden 100 patienten geholpen.

Dan wachten hem nog 50 zieken in het Inlandsch Hospitaal en zij die aan huis moeten geholpen worden. Wanneer men dan even bedenken wil, dat de eenige Europeesche Geneesheer in de Minahassa verder ook nog Quarantaine- en Havenarts is, Opziener van de Vaccine, belast met de behandeling van gevangenen en rechthebbende ambtenaren, de behandeling en de keuringen der soldaten en recruten en gewapende politiedienaren mitsgaders hunne vrouwen en kinderen en het gereedmaken der medicijnen, dan is van 's morgens vroeg tot 's avonds laat iedere minuut bezet en menige nacht wordt hem afgenomen van zijn welverdiende rust. Wel "verdiend», doch slecht betaald.

Zonder in bespiegelingen te willen treden over het verre van weelderige militaire tractement, wil ik voor hen die dit nog niet weten aan de vergetelheid ontrukken dat voor alle bovengenoemde werkzaamheden: dus 30.000 consulten per jaar, gevangenen behandeling, gewapende politie enz., als vallende onder den Burgerlijken Geneeskundigen Dienst, den Officier van Gezondheid eene belooning van zegge en schrijve vijftig gulden 's maands wordt toegekend. Zonder bitter te worden mag men deze betaling verre van "vorstelijk» noemen.

En dat na een alles behalve achturigen werkdag dan de lust ontbreekt om dit werk voor den Burgerlijken Geneeskundigen Dienst breed voort te zetten door de bestrijding van volksziekten, de oprichting van Hospitalen en Ziekenverpleging ter hand te nemen, is dit niet te verontschuldigen? De lust daartoe moet er zijn of geboren worden ondanks het traktement.

Behalve hierdoor wordt de lust bij den medicus om geneeskundige toestanden te verbeteren nog verminderd door de onwaarschijnlijke langzaamheid waarmede, langs allerlei autouriteiten, voorstellen vasten vorm aannemen: Gebrek aan tijd, gebrek aan personeel, onvoldoende bezoldiging, onvoldoende vlugheid van tempo in afdoening van zaken, de gewone klachten van 
hem, die op de omslachtige wijze van werker, die bij gouvernementsinstellingen nu eenmaal onvermijdelijk schijnt te moeten zijn, is aangewezen.

\section{IV.}

Deskundige hulp.

Er zijn in de Minahassa: een Europeesch geneesheer, twee Gouvernements Indisch Artsen en een Inlandsch Hospitaal te Menado, als officieele en deskundige hulp; over niet officieele, semi-deskundige en niet-deskundige hulp later.

Hoewel ik van ervaringen overal al wist dat de hulpmiddelen, die den geneesheeren ter beschikking worden gegeven, met alle beschrijving spotten, had ik in de Minahassa betere en andere toestanden verwacht.

Het wordt langzamerhand beter in Indië; op Java en ook hier en daar in de Buitenbezittingen verrijst al soms een menschwaardig ziekenhuis, maar ik kan oprecht getuigen bij mijne bezoeken en mijne werkzaamheden in de ziekeninrichtingen voor lnlanders in Indië van de eene verbazing in de andere te zijn gevallen.

Laat ons echter bij de Minahassa blijven. Wat trof ik 4 jaar geleden aan op het gebied van ziekenverzorging?

Nergens in Indië meer onderwijs dan in de Minahassa; ontelbare lagere scholen, een Mulo-school, die aan bouwen alleen zes ton kost, een landbouwschool enz., ik struikelde "par manière de dire over leeraren, onderwijzers, bedienaren des woords en zendelingen. Wordt dus geestelijk de Minahasser haast overladen, worden tonnen gouds uitgegeven voor schoollokalen en onderwijzers-salarissen, voor de geneeskundige verzorging van de lichamen, die deze aldus gecultiveerde geesten bevatten, was, kan men gerust zeggen, haast niets aanwezig.

\section{$\mathrm{Ziekenhuis.}$}

Een ziekenhuis - met 4 zalen, sombere hokken met tralies waarin tweepersoons britsen van hout, die wemelden van ongedierte, daarin de zieken "verpleegd" door een "ziekenvader , twee opgeschoten jongens en twee meiden, die geen van allen gediplomeerd waren, en behalve de ziekenvader, welke brave man zijn best deed om ten minste een verpleger na te bootsen, niets van verpleging begrepen. 
Dikwijls heb ik mezelf afgevraagd: "hoe komt het toch dat bij het z.g. beschavingswerk de geneeskundige verzorging achter aan komt, terwijl zij vóór behoorde te gaan? Een leek kan dit ook niet begrijpen. Het is n.l. de struisvogel-politiek van den gezonden mensch.

De gezonde leek rekent niet met ziekten. Op geneeskundig gebied is een leek buitengewoon onlogisch en onredelijk, veel erger dan op elk ander voor hem vreemd terrein.

:Als wij nu nog eens in de Minahassa wilden beginnen met de zieken hulp te bieden, hoe zouden we dat dan inrichten?

Zouden we dan niet beginnen met te bouwen een keurig, vriendelijk Hospitaal met voldoend geschoold personeel: Inlandsche verpleegsters onder Europeesche verpleegsters werkzaam?

Zouden wij dan geen ruime, frissche polikliniek bouwen met de noodzakelijke instrumenten, badkamers, onderzoekkamers voor mannen en vrouwen, oogspiegelkamer, gelegenheid voor zoogenaamde kleine chirurgie, een klein laboratorium voor vluchtige onderzoekingen van urine, uitwerpselen, een verbandkamer, enz.?

Ja toch immers?

Maar zoo gebeurt het haast nooit. We beginnen met soldaten en zendelingen en dan pas veel later komt de ziekenverzorging ter sprake. Als zieken-tehuis vond ik hier de boven beschreven middeleeuwsche inrichting. Voor de poliklinische behandeling van de 100 patienten per dag beschikte ik over twee ongediplomeerde Hospitaalsoldaten en twee dwangarbeiders; als localiteit twee "kamers» in het Fort van 3 bij 4 meter met ruwen steenen vloer, waarin een onderzoektafel, een kast met luttele instrumenten, een tafel en een stoel, petroleumblikken en houten spuwbakken voor bloederige en etterige verbanden en verder niets. De geneesheer moet zijn eigen instrumenten gebruiken. Ik, liet met cement en verf iets verbeteren, kocht een schrijftafel en een paar behoorlijke stoelen in mijn spreekkamer om ten minste me niet al te onbehagelijk te voelen, maar veel te veranderen viel er niet.

$\mathrm{Er}$, was niet eens schoon water om de handen te reinigen; daarvoor diende een email waschkommetje, kortom er was en is niets. Ik heb beklagenswaardige collega's gekend, die met doffe gelatenheid in dergelijke omstandigheden zijn blijven werken. I $\mathrm{k}$ heb er zelfs gekend, diẹ. verzoend werden met de onmogelijke toestanden. 
Ik kon daarin nu eenmaal niet berusten.

En zoo heb ik in de 4 jaar van mijn verblijf te Menado op al deze dwaasheden gewezen en gestreden voor verbetering. Zoo leidde ik zes Inlandsche meisjes op voor verpleegsters; zoo werd een Europeesche gediplomeerde verpleegster aangesteld, zoo werd het Hospitaal uitgebreid, het gevangenis uiterlijk weggenomen, ijzeren kribben aangeschaft, de voeding verbeterd, kraamkamer, kinderzaal, aparte kamers voor ernstige ziekten bijgebouwd enz. enz., kortom er werd getracht iets van het bestaande ziekenhuis te maken, en thans zijn de opgeleide verpleegsters in een zusterhuis ondergebracht en met succes werkzaam onder leiding van de beproefde Europeesche verpleegsters en komt er ten minste iets van de bedoelingen van den geneesheer terecht bij behandeling van zijne zieken.

De verbouwing van het bestaande Hospitaal is nu beëindigd. Met dit ziekenhuis zal men zich moeten behelpen tot het door mij ontworpen plan voor een groot centraal Hospitaal voor de Residentie Menado annex krankzinnigen-tehuis, zal zijn uitgevoerd.

Met dit plan heb ik getracht de Minahassa een behoorlijk ziekenhuis te verschaffen. Ik zal dit plan hier niet verder bespreken, ik volsta alleen met te zeggen, dat het geeft een modern behoorlijk ingericht Hospitaal voor 150 zieken, annex een tehuis voor 24 krankzinnigen, en dat het voldoen zal aan de eischen, die voor ligging en verzorging van zooveel patienten tegenwoordig moeten gesteld worden. De beschrijving van deze plannen zou voor dit bestek te ver voeren.

V.

Hulpziekeninrichtingen.

Behalve de reeds genoemde twee Indische artsen zijn er nog talrijke hulppredikers, die de geneeskunde uitoefenen.

Te Sonder is eene hulpziekeninrichting waar twee gediplomeerde verpleegsters polikliniek houden en patienten opnemen; door haar opgeleide Inlandsche meisjes en jongelieden helpen daarbij. Eveneens te Tomohon is eene dergelijke inrichting.

Ik heb de grootste waardeering voor de goede bedoelingen dier inrichtingen. Tal van eenvoudige gevallen, voetwonden, huidziekten worden daar behandeld en genezen. Bij inwendige geneeskunde houdt echter de goede bedoeling geen gelijken tred met kennen. 
Doch menschen, die gewend zijn, "tot zichzelf in te keeren" zullen in de toekomst de eersten zijn, die bij te verwachten, meerdere, deskundige hulp en betere geneeskundige toestanden die zieken den medicus toezenden.

Hoewel alleen al door ontstentenis van medische hulp die inrichtingen slechts in enkele gevallen bevredigend kunnen werken, en door hunne primitieve inrichting feitelijk als ziekenhuis moeten worden afgekeurd, hebben zij ook naast het komende groote Hospitaal reden van bestaan, als zij zich beperken tot poliklinisch werk binnen het bereik van hun kennen en het verplegen van rust-behoevenden en herstellenden.

Er zou van elk dier inrichtingen een sanatorium kunnen worden gemaakt, daar zij in de bergen gelegen zijn.

Men heeft mij wel eens de vraag gesteld, waarom dan een centraal-hospitaal niet beter geplaatst zou zijn in het bergland.

Het antwoord daarop luidt: om dezelfde redenen waarom men bijvoorbeeld in Nederland de groote hospitalen niet in Ooltgensplaat of Waddinxveen bouwt, hoewel het klimaat daar wellicht beter is dan in Amsterdam.

Voor ondergrens waarbij nog even iets bereikt kan worden, acht ik voor dit gebied met 220.000 inwoners ten slotte noodig: Een Europeesch Geneesheer, 5 Indisch-Artsen, een centraal Hospitaal te Menado voor 150 lijders, annex krankzinnigentehuis voor 24 patienten, met polikliniek gebouw. In het Hospitaal een ziekenauto, die binnen enkele uren uit alle hoeken en gaten van de Minahassa de patienten kan weg halen, waartoe telefonische gemeenschap noodzakelijk is.

Van groot voordeel is daarbij het scherp omschreven gebied van de Minahassa en het mooie wegennet en de betrekkelijk geringe uitgestrektheid. Op andere eilanden zou een centraal Hospitaal nog niet een klein deel van het op deze inrichting aangewezen gebied kunnen «bestrijken». Hier gaat dit om andere redenen gemakkelijk.

Voor het Hospitaal zullen verder noodig zijn: minstens drie Europeesche verpleegsters en een dame voor de huishouding voor het zuster-tehuis, benevens 18 Inlandsche verpleegsters en verplegers.

Vanuit dit Hospitaal, als geneeskundig centrum, kan verpleging, huisbezoek, enz. worden ondernomen.

Ik zal niet taxeeren hoeveel een dergelijke geneeskundige 
toestand als ik schetste zal kosten, maar ik vermoed minder dan de zes ton toegestaan voor éér school en het traktement van het geheele geneeskundige personeel daarvan zal wellicht blijven beneden dat van het personeel van één onderwijsinrichting.

Is dit plan uitgevoerd dan zijn wij eigenlijk daar gekomen waar we moesten begonnen zijn.

Voor, of tegelijk met, geestelijke verzorging verbetering van hygienische toestanden, verzorging van het zieke lichaam.

De Inlander, bevrijd van zijne volksziekten zal ontvankelijker zijn voor onze cultuur.

Tegelijk met, of voorafgaande aan, onze pogingen om hem de zegeningen van het Christendom en onze beschaving te brengen bestrijde men de volksziekten, later met name te noemen, en geneze, zoo mogelijk, zijn ziek lichaam.

VI.

Verloskundige hulp.

Tot het geneeskundig personeel behooren verder nog de vroedvrouwen, die een hoogst nuttig element vormen. Van hunne diensten wordt een ruim gebruik gemaakt. Alleen in bijzondere gevallen, en dan nog meestal op haar advies, wordt een geneesheer ontboden bij verlossingen. Waar de vroedvrouw dikwijls al te laat ontboden wordt, komt men dan voor verwaarloosde gevallen te staan, die men alleen nog bij natuurvolken aantreft, die nog niet van de noodzakelijkheid van deskundige hulp in die gevallen doordrongen zijn.

De meest wanhopige kunstverlossingen heb ik dan ook tallooze malen moeten verrichten, waarvan de beschrijving hier niet op haar plaats zou zijn.

Vaccinateurs.

De 6 vaccinateurs die in de Minahassa werkzaam zijn vormen een zeer voldoend onderdeel. Zelfs zou men hun aantal kunnen beperken, aangezien elk ressort niet groot is. Men kan over dit resultaat tevreden zijn. De pokziekte vroeger geregeld voorkomende in jaarlijksche epidemieën heeft afgedaan.

Waar het salaris der vaccinateurs klein is, acht ik het niet verstandig hun werk uit te breiden door inkrimping van hun aantal. De kosten voor de vaccinatie vormen een nietig bedrag. 
Elke vaccinateur heeft een vast ressort dat hij in een vast aantal tournées moet afreizen; bij de verrichte inentingen noteert hij de namen der personen, waarbij die kunstbewerking geschiedde, in een dagboek aan. Die dagboeken staan weer onder contrôle van den opziener der vaccine (de Officier van Gezondheid).

Op de poliklinieken worden aan alle rechthebbenden, dat zijn dienende en gepensionneerde militairen en ambtenaren met een maandelijksch traktement beneden 150 gulden en alle behoeftigen, gratis medicamenten verstrekt, die alweer door den Officier van Gezondheid in de apotheek worden gereed gemaakt.

\section{Genezers.}

Ten slotte ontvangt de bevolking nog adviezen op geneeskundig gebied van alle geestelijken en hulppredikers en hunne Inlandsche genezers (zoo is, meen $\mathrm{ik}$, de term tegenwoordig voor hen die zonder opleiding en vakkennis geneeskundig werk verrichten).

De zendelingen hebben gewoonlijk geneesmiddelen tot hunne beschikking, die zij de bevolking gratis verstrekken. Als in de toekomst deskundige hulp beter bereikbaar zal zijn, kan van deze helpers worden verwacht, dat zij de bevolking zullen aansporen die hulp meer te zoeken dan thans te doen gebruikelijk is.

\section{Gevoelde behoefte aan geneeskundige hulp.}

Het gebruik, dat de bevolking van de beschreven hulp maakt is gering te noemen in verhouding tot wat het moest zijn; het vertrouwen in Europeesche geneeswijzen is nog klein.

Immers een Hospitaal met 50 lijders geeft niet de behoefte weer van 220.000 ingezetenen.

Maar natuurlijk zal, wanneer goede verpleging in een vriendelijk hospitaal, waar lig- en diëetkuren mogelijk zijn, waar geopereerd kan worden, reclame maakt, het Hospitaal voor 150 lijders, dat ik ontwierp, al spoedig te klein blijken te zijn; er is bij dit plan dan ook op uitbreiding gerekend.

Wanneer de gelegenheid geboden wordt komt de behoefte van zelf.

Men stelt echter de zaak onjuist voor, wanneer men zegt dat de Inlander behoefte heeft aan méér geneeskundige hulp. Integendeel, de Inlandsche artsen kunnen het werk hier gemakkelijk af, 
Wel vragen de voorgangers van den Minahasser deze hulp voor hen, doch de behoefte daarvoor bestaat nog slechts in geringe mate.

Zoodat wij geneeskundigen, de geboden hulp onvoldoende achten en de inlander zelf niet. Wat moet men soms geen moeite doen hen tot eene opname in het Hospitaal te brengen.

Toen ik hier pas kwam heb ik dikwijls in "arren moede»die poging opgegeven, omdat ik in mijn hart zelf van die Hospitaalverpleging niets verwachtte.

Gelukkig is dit nu anders geworden, en menige patient heeft nu zijn leven aan die verpleging juist te danken.

\section{VII.}

Inlandsche geneesmiddelen.

Ondanks alle nasporingen is het mij niet mogen gelukken eenig bijzonder specifiek Minahassisch Inlandsch geneesmiddel te ontdekken. Dezelfde kruiden als overal elders in Indië worden gebruikt, alleen in minder groote verscheidenheid.

Ondanks alle wonderen ervan verhaald, heb ik er geen van gezien. Mij zal, evenmin als anderen geneesheeren, de opmerking worden bespaard, dat wij niets van "Indische kruiden» willen weten. Hoewel het slecht preeken is tegen overtuigden van het tegendeel, wil ik toch nog even hier opmerken, dat dit onbillijk is; alle mogelijke en onmogelijke kruiden worden door de geneeskundigen beproefd, de bestanddeelen van geheime en andere middelen worden geregeld in het laboratorium onderzocht en werkelijk goede geneesmiddelen, dankbaar aanvaard. Is het anders gegaan met de chinine, de Ipecacuanha wortel enz. enz.? Alleen laten wij onze patienten niet meer kauwen op chinabast, maar geven hun het werkzame bestanddeel in een versuikerde pil, wat wel zoo aangenaam is en spuiten hen onderhuids de emetine in, inplaats van hen de martelende thee of poeder van den braakwortel te laten innemen.

Het is bekend dat het eene jaar een plant meer werkzame bestanddeelen van een bepaald geneesmiddel heeft in zijne bladeren of bast of wortel dan het andere en dan nog een jong blad meer of minder dan een oud - en de eene plant meer of minder dan de andere. Wanneer nu dat gehalte scheikundig bepaald wordt, dan kan men daarmede rekenen; voorschriften 
als van «een hand vol» hebben nooit mijne voorliefde gehad. In de artsenijkunde hebben wij eerder te veel dan te weinig Indische kruiden overgenomen, het weinige koren onder het kaf is ieder Indisch Geneesheer bekend.

De bevolking gebruikt naast al deze aftreksels inwendig, en uitgekauwde bladeren of tabak of sirihpruimen op wonden en ontstoken lichaamsdeelen uitwendig, ók «Westersche» medicamenten.

Onder de zonderlinge uitspattingen der empirie trof ik o.a. aan inkt gesmeerd op uitslag, tot zelfs in het gezicht; niet onmogelijk dat de tannine, de ijzerverbindingen en de kleurstoffen soms genezend werken, maar de remedie is hier toch erger dan de kwaal.

Eenmaal werd mij een geneesmiddel te koop aangeboden tegen beri-beri. De verkooper beweerde er honderden lijders mede genezen te hebben; het was een zuiver plantaardig middel. $\mathrm{Nu}$ deelde ik hem wel mede, dat we al een schitterend geneesmiddel hadden, óók zuiver plantaardig en Indisch in den vorm van katjang hidjoe ('n soort groene erwt) maar waar dit middel langzaam werkt en het aangeprezen zoo snel, volgens zijn zeggen, nam ik een proef op 10 lijders aan beri-beri. In 10 dagen was geen spoor van eenige verbetering te ontdekken. Wij hebben ze toen maar weer op de "oude» manier genezen.

Zoo is het met veel "Indische kruiden».

Niet systematisch beproefde, bij onbekende kwalen toegepaste middelen van chemisch onbekende samenstelling door personen, die oorzaak en gevolg niet kunnen beoordeelen en zooal wel de symptonen dan toch de ziekte niet herkennen, kan men nog meer «in het wilde weg werken»?

\section{VIII.}

\section{Lichamelijke ontwikkeling.}

Wij hebben dus nu gezien over welke hulp de Minahasser bij ziekte de beschikking heeft, en welk gebruik hij daarvan maakt.

Hoe leeft nu de Inlander, hoe is zijne lichamelijke en geestelijke ontwikkeling, hoe huist hij en voedt hij zich?

De Minahasser is klein en gedrongen van gestalte, hij (of zij) beantwoordt zelden aan Westersche begrippen van schoonheid.

Hij is grof en stevig gebouwd; bij vrouwen vallen op de 
breede heupen en plompe voeten en enkels - de sierlijke gang van eene Balineesche of Javaansche ziet men hier nooit. De beenen zijn te kort voor het bovenlijf, het gelaat soms niet leelijk, maar gewoonlijk te breed, met uitstekende jukbeenderen; er is opvallende overeenkomst met den bouw van een Japanner. De Minahassa is een bergland vandaar de ongeproportioneerde ontwikkeling der beenspieren bij den Inlander. De bewoners van de smalle kuststrook missen dit, doch zij zijn natuurlijk verre in de minderheid.

Opvallend is de lichte kleur der huid; het haar is echter, als bij alle volken in onzen Archipel zwart en grof, een enkele maal bruinzwart, wat er, als wankleurig zwart, al zeer onaesthetisch uitziet.

Opvallend is het groot aantal albino's.

De zeer leelijke ongepigmenteerde huid, die lichtschuwe oogen, maken deze menschen beklagenswaardig. Een reden voor dit groote aantal albino's is mij onbekend, of het zou moeten zijn een degeneratie verschijnsel ten gevolge van het groote aantal familiehuwelijken onder dit kleine volk, dat weinig verkeer heeft met naburige landen.

De Minahassa is immers een afgerond geïsoleerd geheel.

Een flink, forsch gebouwd menschenras ten slotte.

\section{Geestelijke ontwikkeling.}

Toen ik vier jaar geleden hier werd geplaatst, had ik mij uit de literatuur een idee getracht te vormen omtrent land en volk, en nog levendig staat mij mijn eerste autotocht door de Minahassa voor den geest. Een vreemde verwarrende indruk die eerste, en de beste, helaas.

Die, uit de verte, zindelijk aandoende huïsjes, netjes op een rij, met tuintjes er voor en geschoren haagjes, hier en daar een kerkje aan het eind van een rechten zijweg, de goudsbloemen, de dahlia's, de inwoners langs den weg met gestreepte broek en witte kabaja en stroohoed, of de zwarte halve hooge vilthoed, die men vroeger veel in België zag, terwijl men in het Hollandsch begroet werd met «daag» of «dag m'neer»... waar was ik? In Indië of in de Klundert, Tjitjerksteradeel of het Oldambt?

Hier en daar klonk het "Wien Neerlandsch bloed», zelfs meerstemmig, me te gemoet. 
Een oppervlakkig beschouwer is verteederd, zijn kritiek in slaap gesust.

Later heb ik dit anders ingezien.

Merkwaardig die overeenstemming tusschen Hollandsch en Minahassisch. Geen volk in Indië, dat beter ons zou kunnen nabootsen dan dit, al beginnende met den lichaamsbouw. Is ook de Hollander niet grof en gedrongen? de Hollandsche vrouw. niet berucht om hare "démarche», haar enkels en voeten?

In hoe korten tijd heeft hier de zending niet van een heidensch volk een christenvolk gemaakt (dat heeft bij ons langer geduurd).

Voor 100 jaar was men buiten Menado nog niet veilig en nu; is men overal als onder broeders. In ongelooflijk korten tijd hebben de zendelingen hier wonderen verricht.

Nergens in Indië meer scholen in soorten dan hier; analphabeten zijn uitzonderingen.

De regeering gaf haast te véél op onderwijsgebied; er is eene M.U.L.O.-school, een landbouwschool, overal zijn Hulppredikers, bedienaren des woords.

En ik ben bang, dat nu de zoo flink gebouwde forsche, gedrongen Minahasser geestelijk uit zijn krachten gaat groeien. Er zijn sporen van geforceerde cultuur.

Althans, als de meest beschaafden onder hen, hunne leiders, weergeven hunne gevoelen, dan heerscht er niet geringe zelfoverschatting. De 220.000 Minahassers stellen hoogere eischen en "praten" meer dan de 40 millioen Javanen.

In den Volksraad en Minahassaraad wordt gesproken over vrouwenkiesrecht en een Universiteit alsof het niets is.

Een volk dat 100 jaar geleden nog in het zwartste Heiden-: dom sluimerde en wild was, tot koppensnellen toe, is daar, zelfs met stoom opgeleid, nog een paar honderd jaar van af. En eene Universiteit voor Indië behoort toch zeker op J a va in de eerste: plaats. Men zet die toch in Holland ook niet op de Drentsche hei?

Een volk dat zijn werkelijk beschaafde mannen nog bij tientallen en de beschaafde vrouwen bij eenheden moet tellen.

Die geestelijke zelfoverschatting vergoelijkt men bij kinderen in de vlegeljaren, bij volwassenen doet ze minder aangenaam aan.

Alles beter weten, alles beter kunnen: voor de regeering een zware taak dit volk te leiden.

De Bestuursambtenaar staat hier geheel anders tegenover het volk dan elders in Indië. 
Het is wat gauw gegaan, en daardoor minder grondig.

"Egratignez le Russe et vous trouvez le Barbare» krab het vernisje weg en de heiden komt voor den dag.

Dit volk schijnt verder dan het is.

Het nam snel aan, het imiteerde goed, maar de eigen inwendige ontwikkelingsgang kon dit tempo niet volgen.

Over de resultaten van de "kerstening» heb ik geen ervaring, maar wel is het jammer dat zij die dit volk zoover gebracht hebben als het is, waarvoor hun den grootsten lof niemand kan onthouden, niet konden voortbouwen op wat zij vonden.

Er zal toch wel een begin van eigen kunst, eigen kleeding, eigen huizenbouw, eigen muziek geweest zijn.

Wellicht is hier de zendeling, die wel ernstig geloovig maar niet kunstzinnig genoeg was, niet onschuldig aan.

De stroohoed, die slaapbroek en kabaja, die goudsbloemen, die pietepeuterige dorpsstraatjes met streng Middeleeuwsche huisjes, allemaal in dezelfde blokkendoos, of koekebakkers-stijl opgezet, zijn hun bijgebracht door hun voorgangers, die dit blijkbaar zelf mooi vonden.

De slechte imitatie streelde mijn verborgen gevoel van Hollandsche zelfingenomenheid; bij nader inzien betreurde ik het tevergeefs naar eigen kunst, eigen muziek-, huizenbouw, huisvlijt te moeten zoeken.

Niemand kan uit de Minahassa iets eigens meebrengen.

Geen oorspronkelijke versiering, geen houtsnijwerk, geen eigen kleuren of lijnen-combinaties.

Iedereen kent bijvoorbeeld de, soms fraaie, versieringen met snijwerk van balken van woonhuizen of wapenen bij de primitiefste volken. Dit is hier natuurlijk óók geweest, doch heeft men te gronde laten gaan en er Westersche bazar-prullen voor in de plaats gegeven.

Wee het volk dat geen eigen kunst en taal heeft! Aan de opvoeders en leiders de taak om het verzuim te herstellen. $\mathrm{Er}$ moeten nog sluimerende resten zijn van eene eigen volkskunst. Daar bouwe men op voort, dat is beter dan slechte imitatie.

Zooals na de vlegeljaren gewoonlijk eene periode komt waarbij men meer en meer tot begrijp van zijne eigen gebrekkigheid geraakt, zoo zal dit volk leeren begrijpen dat de weg, die een Europeesch volk in 2000 jaar aflegde niet in honderd door hen kan worden afgehold.

Dl. 80 , 
Daar moet eerst nog eens een enkele eeuw aan gewerkt worder. Er zijn zelfs verschillende momenten te noemen, waarom dit in het vervolg, na het éérste vernis, langzamer zal gaan.

Ten eerste het klimaat: $\mathrm{Er}$ is geen koude. Ten tweede: er is geen honger; iedereen krijgt te eten; er is haast geen armoede. De noodzaak tot arbeid wordt daardoor lang zoo zwaar niet gevoeld als door den Europeaan.

Er zijn pessimisten die zeggen: "het volk is al voor goed bedorven». Een sterk menschenras, met gebleken aanpassingsvermogen, dat blijkt reeds nu enkele tot studie geschikte landskinderen te bezitten, kan zich verder verbeteren en ontwikkelen.

Het zoeke verdere ontwikkeling door eigen cultuur van eigen kunst en raseigenschappen, het streve naar eigen literatuur en eigen taal; dan kan het groot worden in die dingen, die voor een zóó klein volk, dat het in de wereld nooit iets «te beweren» kan hebben, zijn weggelegd.

\section{Militaire neigingen.}

Merkwaardig, dat dit volk ons leger de meeste en van de beste soldaten heeft geleverd, wat een gevolg is van een bijzonder goede eigenschap en wel de zucht om meer van de wereld te zien, het verder te brengen. Veel is er geschreven over het contvolken» van de Minahassa door deze werving.

Toen in 1913 en 1914 het leger uitbreiding behoefde, hebben zich 4000 recruten aangemeld. Dit was een groote aderlating en herhalingen daarvan zouden zeker niet aan te bevelen zijn, maar geschaad heeft het niet. Het kinderen-aantal is nog voldoende en het gewone aantal van vijftien recruten per maand is volstrekt niet te groot voor het zielental. Maar de sterfte is te groot onder de volwassenen en eerst recht onder de kinderen.

En de influenza heeft in 1918 oneindig veel grootere offers gevraagd dan het leger. Merkwaardig onjuist is ook de bewering, die men vaak in tendentieuse geschriften leest over «slechte behandeling» van de soldaten en hun verlangen den dienst te verlaten.

In de vier jaren, dat ik keurde voor reëngagementen, was het een hooge uitzondering dat een soldaat niet na zes jaar opnieuw teekende. Ook is volstrekt onwaar, dat er pressie op de werving uitgeoefend wordt. Steeds moeten honderden afgewezen worden en men moet de vreugde zien der aangenomenen om 
te begrijpen hoe dol graag ze soldaat worden. Het is eenmaal een volk met de neiging tot militairisme van elk gezond kind. Als militair verzorgt de Minahasser zijn uiterlijk zeer: Een oudmilitair is een persoon "van gewicht» in dit land, en is na de «Compenie» gediend te hebben er heusch niet minder op geworden. Hij heeft het gebruik van water en zeep geleerd en is na zes jaar niet meer te herkennen, zóó is zijn uiterlijk verbeterd. Orde, regelmaat, tucht, kunnen in geen enkel menschenleven kwaad doen. Ik kan hier dit onderwerp niet verder uitspinnen, maar volsta met als mijn overtuiging mede te deelen, dat de Minahassische recruut op een zoo lagen trap van beschaving en zedelijkheid staat, dat de eerste zes jaar van zijn dienstverband hem in elk opzicht ten goede komen.

$\mathrm{X}$.

$\mathrm{Hu}$ isvesting.

De geneeskundige verzorging zooals ik die schetste, zal voorts betere begrippen omtrent huisvesting en voeding kunnen brengen.

Het eenige voordeel van het Minahassische huis is, dat het op palen staat of steenen neuten. Daarvoor is de vervuiling in huis minder erg; men moet nu altijd een trap op om in huis te komen, en daar het houten huizen zijn, is ook de vloer van planken, en vallen vele ongerechtigheden tusschen de naden door, wat anders, tot een pap vermalen, door de voeten der bewoners door het huis zou worden "versleept».

In de voorgalerij der woning treft men een tafel aan met een paar afschuwelijke wipstoelen en een enkele wangedrochtelijhe oleographie, veelal van den sultan van Turkije of den keizer van Duitschland, doch ook wel van ons Vorstenhuis. Daarachter komt het woonhuis. Van de voorgalerij wordt alleen bij visite gebruik gemaakt. Men vindt houten bedden, veelal met klamboe, die echter alleen voor versiering dient, niet voor de muskieten zooals een argeloos mensch zou denken.

Dit blijkt uit het feit, dat als het bed tegen den muur staat er aan den muurkant dikwijls geen klamboe is, soms evenmin een plafond in de klamboetent, terwijl de vuist groote gaten, die er nooit in ontbreken, alleen al bewijzen zijn voor mijne opvatting. 


\section{Zindelijkheid.}

Met water opnemen van vuil gebeurt nooit, stof afnemen evenmin; alle meubels zijn grauw van stof.

Is de bouwtrant van het huis dus gunstig omdat veel vuil onder het huis terecht komt, wat er anders in zou blijven, de accessoires zijn zuiver Inlandsch, d.w.z. meer Inlandsch dan zuiver. Aarden vloer, privaat ò afwezig, òf vlak in de nabijheid van de keuken, welke men beter kookhok kan noemen.

Liefde voor inboedel, in den vorm van de, bij de Hollandsche huisvrouw haast ziekelijke, zucht tot boenen, plassen en wrijven tot alles glimt als een spiegel, bestaat niet. Alles is grauw en grijs; na gekocht te zijn, worden de meubels nooit meer gewreven; reinigen van vloer en houten wanden met water, zeep, soda komt nooit voor. Het meubilair is hoogst primitief en onverzorgd, de kleeren worden zelden gewasschen, en dan gewoonlijk zonder zeep, en gedragen tot de boel in flarden is versleten.

De mannen en vrouwen vertoonen wel neiging tot opschik, maar zindelijkheid ontbreekt.

Het baden geschiedt ter verwisseling, niet tot reiniging, zeep wordt veel te weinig of in het geheel niet gebruikt.

In de huizen is de wandluis haast vaste gast; een kind of meisje zonder hoofdluizen is uitzondering.

De noodzakelijkheid van handen wasschen voor en na eten en andere diergelijke verrichtingen wordt niet ingezien; nagels worden niet gereinigd. Huidziekten, beenwonden, klierzwellingen, zijn daardoor algemeen en zelfs de allerbeschaafdsten onder hen staan wat zindelijkheid aangaat en begrippen van hygiene mijlen ver van wat de Westersche cultuur al een eeuw geleden als ondergrens voor beschaving aannam. Ik zal hen daar geen verwijt van maken, integendeel bewonder ik hoe in zoo korten tijd zooveel is bereikt, maar grappig is het dan te hooren spreken over "kami orang ontwikkeling» (wij menschen van ontwikkeling).

Verblind door den uiterlijken schijn en in de gelegenheid, door het gemak waarmede, sedert de uitgebreide klappercultuur zoo bloeit, het geld verdiend wordt, alle Europeesche "poespas» aan te schaffen.

De waarde van het geld is hun niet voldoende bekend. Het wordt te gemakkelijk verdiend en de klappercultuur is een "luie» 
cultuur, of liever, men kan de boomen haast onbegrensd verwaarloozen, ze leveren toch nog vruchten. Het zoo gemakkelijk verkregene wordt niet op prijs gesteld. Het zoo verheffende van intensieven arbeid, lichamelijk, zoowel als geestelijk, is hun onbekend. Harde werkers zijn er, op enkele uitzonderingen na, niet.

Jammer dat nu daarvoor veel te veel naar het Hollandsche voorbeeld moet worden gezien.

Waar de Minahasser in vergelijking met andere Indische volken, eerder sterk dan zwak van lichaam is, zijn ook zijne hersenen niet minderwaardig en zullen deze bij de voor hersenarbeid bestemde individuen onder hen, door langzame evolutie en rasverbetering en selectie langzaam in den loop der eeuwen geschikt worden, tot zuiver en scherp begrip van veel, wat hun thans nog verborgen moet blijven.

De lage trap waarop hun zindelijkheid staat, hun gering begrip van eischen van voeding en ziekenverzorging, maken dat tal van ziekten een aanval op dit ras doen en de sterfte veel grooter maken dan noodig zou zijn bij hooger beschavingspeil.

\section{Voeding.}

De Minahasser voedt zich zeer eenzijdig, veel eenzijdiger dan bijvoorbeeld de Javaan.

In hoofdzaak eet hij rijst en mais, groenten haast niet, een stukje visch of vleesch, lang niet altijd, en wel altijd Spaansche peper. Helaas besproeit hij een en ander wel wat rijkelijk met sagoeweer of palmwijn. Van de beweerde onschadelijkheid van deze niet onbelangrijk alcoholhoudenden drank kan ik niet veel gelooven om de volgende redenen:

$1^{\text {e. }}$. Geen enkele alcoholhoudende drank is op jeugdigen leeftijd onschadelijk bij dagelijksch gebruik. En de Minahasser begint al zeer jeugdig en eindigt met dit dagelijksch gebruik bij den dood.

$2^{\text {e }}$. Bij de keuringen van soldaten viel mij op dat de urine, nadat $\mathrm{zij}$ den avond te voren sagoeweer hadden gedronken zoo dikwijls eiwit bevatte.

Een onschadelijke drank mag de nieren niet dusdanig prikkelen; vandaar dat de soldaten bij keuringen elkaar den raad geven: "drink geen sagoeweer».

$3^{\text {e }}$. De Inlander zelf beweert van véél sagoeweer gebruik "Soepit» te krijgen, wat dan bleek te zijn eene chronische jichtige ge- 
wrichtsontsteking. $\mathrm{Al}$ is het nu geen "volkskanker» als onze jenever, en is dronkenschap zeldzaam, onschadelijk is het niet en de groote sagoeweer drinkers zijn juist als bij ander alcoholmisbruik: suf.

Trouwens in Europa zijn jong bier, jonge wijn bekend als ongunstig werkend voor jicht en blaas- en niersteen vormend en sagoeweer is altijd jong.

De voeding en verzorging van het kind is erbarmelijk, de kindersterfte is dan ook vreeselijk te noemen.

\section{Ziekenverpleging te huis.}

Wanneer de moeder haar zuigeling zelf voedt gaat het nog. Het kind wordt dan echter steeds aan de borst genomen wanneer het maar even huilt, geen wonder dat bij een dergelijke onregelmatige afname de productie van melk spoedig vermindert en dan komt er wat anders voor in de plaats, hetzelfde voedsel als we bij andere primitieve volken zien. Hier bijvoorbeeld vaak door de moeder gekauwde rijst, met vuile vingers en nog vuilere nagels tot gore balletjes gekneed. Het kind wordt dan volgepropt tot het half stikt. Is het ziek dan wordt het den geheelen dag rond gedragen, ingesmeerd met allerlei viezigheid en beteekend met roode en zwarte kruisen; in den nood komt bij den jongen Christen nog vaak de oude Alfoer boven.

Ook wordt dan nog al eens geofferd en wierook gebrand en de patient uitgerookt om de booze geesten gunstig te stemmen of te verdrijven; in angst bij ziekten leeft het bijgeloof weer op. "Tout comme chez nous».

Het kind wordt dan gedurende de geheele ziekte niet meer gebaad; geen wonder dat de huidademhaling dan al spoedig zeer beperkt wordt. Elk ziek kind krijgt dan ook een eczeem. Alleen al bij eenig begrip van zindelijkheid bij bereiden van voedsel en van regelmaat in de toediening en bij begrip van huidcultuur zou de sterfte belangrijk dalen.

Hetzelfde geldt ook voor de volwassenen; alleen zijn deze weerstandkrachtiger, ook al omdat wie de eerste levensjaren aan de, goedbedoelde, mishandeling der ouders ontkomt vanzelf robust moet zijn. Ook hier missen we o. a. het begrip van reinigen van zieken en de noodzakelijkheid van rust en diëet. Typhus patiënten en lijders aan longontsteking vindt men zittende met 
harde rijst en gedroogde visch als versnapering. Ook hier is de sterfte onnoodig hoog.

$$
\text { Beri-beri. }
$$

De ziekten, die bij eenzijdige voeding plegen op te treden, als beri-beri, ziet men dan ook veelvuldig. Een voordeel is, dat de bevolking veel eigen verbouwde rijst gebruikt, die minder «mooi» is dan geïmporteerde rijst, d. w. z. de rijstkorrel is slecht ontdaan van het z.g.n. zilvervlies en komt daardoor de bij beri-beri zoo heilzame roode rijst meer nabij dan geïmporteerde rijstsoorten.

Epidemische ziekten. Pokken.

De slechte hygienische toestanden maken dat dit land feitelijk voor elke epidemie openstaat. Alleen het pokkengevaar is, zooals ik reeds beschreef, door de stelselmatige vaccinatie bezworen.

$$
\text { Pest. }
$$

Ook heb ik hoop, dat de Minahassa langer dan andere streken (van Java bijv.) voor pest zal bewaard blijven.

Zooals bekend is wordt deze ziekte in hoofdzaak door de vlooien der pestzieke ratten met hun beet op den mensch overgebracht.

$\mathrm{Nu}$ leeft de Minahasser minder intiem met de rat samen dan de Javaan. In de eerste plaats zijn de meeste woningen van hout, in de tweede plaats staan zij op palen, in de derde plaats zijn de wanden der huizen dus ook van hout en de rustbedden gewoonlijk ook. Rattennesten, als op Java tusschen de dubbele bamboewanden, in de bamboe van de baleh-baleh, in de bamboes als stutten voor dakbedekking, komen dus hier niet voor.

\section{Cholera.}

Voor cholera zijn die gunstige omstandigheden er niet, alleen heeft men te Menado goede artesische putten. De cholera heeft echter herhaaldelijk in de Minahassa gewoed en er hare slachtoffers geëischt. Behalve te Menado treft men nergens verder artesisch water aan; trouwens de wijze waarop dit water den verbruiker bereikt verzekert haast een verontreiniging. De waterleiding, die aangenomen is, zal hierin veel verbetering kunnen brengen. 


\section{In fluenza.}

De groote Influenza-epidemie zal mij altijd bij blijven als een benauwende droom. Wanneer ik zoo naga welke epidemische of besmettelijke ziekten te Menado woedden tijdens mijn verblijf dan wordt het alles overheerschende herinneringsbeeld wel gevormd door de "geheimzinnige» Spaansche ziekte of Influenza.

Zooals overal heeft ook in de Minahassa deze ziekte op ontzettende wijze huis gehouden.

In Juli en Augustus 1918 begon het te Menado als een kleine epidemie, die zeer goedaardig verliep, doch eind October kwam de ziekte met vernieuwde woede terug, en duurde toen drie maanden.

De grens van het uithoudingsvermogen van den medicus was toen ób bereikt. Als men de uren rust optelde die men in die dagen genoot, zou men tot een verbluffend klein aantal komen.

Tal van collega's zijn in den strijd tegen deze ziekte gesneuveld op het veld van eer, hunne weduwen, zonder verhoogd pensioen, achterlatend. Nergens mocht ik een woord van appreciatie lezen voor den enormen arbeid door elken geneesheer in dien tijd gepresteerd, alleen schampere opmerkingen trof ik in de couranten aan over de onmacht der menschheid deze ziekte te besparen.

Een specifiek middel tegen deze ziekte was er niet en toch kon men "lauweren oogsten» bij behoorlijke symptomatische behandeling, een wakend oog houdende op dreigende hartszwakte en andere complicaties.

Men kon dan toch met diëet, bedrust, ook gedurende de koortsvrije periode, de noodige opwekkende en hartszwakte-bekampende geneesmiddelen veel nut stichten en onheilen voorkomen, door bij complicaties of bij van vroeger bestaande ziekten de zwakke plaatsen te ondersteunen.

Ook hier was de taak van den Internist belangrijker dan veelal wordt toegegeven en begrepen.

Deze ziekte was voor den Inlander nu wel eene ziekte bij uitnemendheid om er zwaar onder te lijden.

Levende van dag tot dag, zich eenzijdig voedende, acht hij zich na de koortsperiode genezen, terwijl dan eigenlijk pas het gevaar goed begint.

Tijdens de koorts en zeker nog acht dagen daarna behoort men bedrust te houden. 
Een Inlander weet niet wat bedrust is, hij slaapt veel, maar kort achtereen. Trouwens een houten brits, of enkele kisten met een ligmatje erop vormen geen ligplaats voor een ernstige zieke.

Ten onrechte wordt, zelfs in vele hospitalen, gemeend, dat een inlander zich pas "senang" voelt als zijn ligplaats dezelfde is als thuis. Dit moge al waar zijn voor gezonden, doch gaat niet op voor zieken.

Een gezonde inlander is des nachts vrij ambulant en rust niet lang achtereen op zijn harde ligplaats.

De zieke Inlander heeft zich, volgens mijn ervaring, altijd behagelijk gevoeld in een ledikant met een matras.

Tehuis volgt de zieke zijn oude gewoonten en staat nu en dan op, gaat naar buiten; en zelfs ook in zijn huis, dat gewoonlijk zeer "doorluchtig" is stelt hij zich bloot aan groote temperatuurswisselingen en wind en tocht.

Het groote gevaar bij Influenza is de longaandoening, en zijne levenswijze werkt die in de hand.

Duizenden gevallen heb ik onderzocht en behandeld, veelal geroepen als het te laat was.

\section{VI.}

Volksziekten.

Al mocht ik de Influenza niet stilzwijgend voorbijgaan, van meer belang zijn de ziekten, die niet bij toeval geïmporteerd zijn, maar voortdurend knagen aan de volksgezondheid.

In de eerste plaats de

\section{Malaria.}

Geen plaats in de Minahassa is voor deze ziekte gevrijwaard, al worden moeras- en kuststreken door het meer voorkomen van de anopheles-soorten (malaria-muskieten) het meest bezocht.

Men vindt alle soorten van malaria. Een Inlander met een niet voelbare milt is dan ook een uitzondering. Meestal doet hij in zijn eerste levensjaren al de malaria op om die nooit meer kwijt te raken.

\section{Voorkomen.}

Het is hier de plaats niet om over het nut van chinineverstrekking in het groot uit te wijden. Iedereen zal het er ten slotte mede eens zijn dat voorkomen beter is dan genezen. Met 
het aanbrengen van die verbeteringen in de hygienische toestanden, waardoor de malaria zal verminderen, kan dan een ruime behandeling gepaard gaan. Die maatregelen zijn spoedig genoemd : draineeren van moerassen, dempen of onschadelijk maken van plassen, vernietigen van broedplaatsen van muskieten in de eerste plaats.

In de tweede plaats voorkomen van muskieten-beet door doelmatig gebruik van klamboes en ten slotte chinine-behandeling, waardoor de parasiet van malaria uit het bloed verdwijnt en dan ook niet wordt overgebracht door een muskiet.

Die maatregelen zijn echter slechts met verbazende moeite door te voeren.

Kon men dan nu nog eens beginnen, met wat we tegenwoordig weten van vele besmettelijke ziekten en volksziekten, met bouwen van steden en kampongs, ja dan, maar nu moet men zich meestal beperken tot «verbeteren» van iets wat haast niet te verbeteren is.

Het lijkt soms wel alsof men voor ligging van nederzettingen en kampongs de slechtste plaatsen heeft uitgezocht die denkbaar waren.

Schoonhouden van erven, opruimen van alle broedplaatsen van muskieten, als : ledige blikjes, potten, bamboestoelen, vochtige donkere gewelven, stilstaande plassen, open putten, aanbrengen van riolen met stroomend water voor afvoer van vuil.

Men heeft hiervoor aparte geneeskundige ambtenaren noodig, die «jacht» maken op die plaatsen, en die voorlichting geven hoe den strijd best aan te gaan.

Daarbij zou als bij pestbestrijding een zachte dwang dienen te worden uitgeoefend, want velen willen niet van verandering weten, omdat zij het gevaar niet kennen en begrijpen.

Wanneer men mij vraagt hoe bijvoorbeeld ter hoofdplaats Menado dit mogelijk zou zijn, dan moet ik bekennen dat dit slechts ten koste van kolossale geldelijke offers zou kunnen geschieden.

Met de malaria zou dan gelijkertijd de zoo frequent in Indië voorkomende Buiktyphus of typheuse koorts verminderen.

$$
\text { Typhus. }
$$

Waar vuile erven en huizen zijn voẹlt naast de malaria de typhus zich tehuis. 
Deze ziekte heerscht in de Minahassa endemisch.

Tallooze gevallen doen zich overal in dit land voor in alle graden, het meest in de omstreken van Menado en Tondano.

En naast de mug ontmoeten wij hier als gevaarlijken vijand van den mensch de vlieg.

Met het bestrijden van dit walgelijke beest, dat ons eten, als het niet afgedekt is, en ons lichaam bij aanraking besmet door haar hebbelijkheid voortdurend ontlasting en braaksel te deponeeren, als resultaat van hare onsmakelijke maaltijden van infectieus materiaal, zullen typhus, cholera, bacilaire en amoeben-dysenterie en tuberculose o. a. verminderen.

Voorwaar, vijanden hebben wij in vlieg en mug grooter dan in alle tijgers en krokodillen in Indië te zamen.

\section{Voorkomen.}

Ook hier dus: verhinderen van voortplanting door het ontnemen van broedgelegenheid, door het aanbrengen van goede riolen, het verplichtend stellen van het bewaren van afval in goed gesloten vuilnisbakken, waarna het vuil behoort verbrand te worden, òf door de inwoners zelf, òf door een reinigingsdienst.

Thans worden mest, spijsresten, en, waar geen privaten zijn, ook uitwerpselen open en bloot overal gedeponeerd.

Privaten en het gebruik daarvan behooren verplichtend te worden gesteld.

In de tweede plaats behooren de vliegenlarven en eieren te worden vernietigd waar ze voorkomen en ten derde de vliegen zelf te worden gedood met lijmstokken, vliegenpapier of vliegenvallen, of door ze dood te slaan.

Spijzen en dranken moeten dus tegen vliegen beschermd worden. Nergens ziet men dit haast. Vleesch- en vischverkoopplaatsen behoorden met gaas te worden afgeschoten en d.g.l.

Men wordt dienaangaande zeer pessimistisch gestemd als men de vreeselijke vervuiling der huizen kent. Welk gevaar muggen en vliegen vormen, men heeft er geen denkbeeld van, men doet er niets tegen.

Kinderen deponeeren hunne uitwerpselen overal in huis.

Hoe de erven er uitzien, blijkt al dadelijk bij een vluchtige inspectie van de erven in het centrum der "stad" Menado. Alles wordt op die achtererven gedeponeerd en blijft liggen. Een varken, vrij rondloopend in deze passende omgeving, gevoelt 
zich daar «in zijn stal». Al deze achtererven behooren tot huizen van notabele Chineezen en Inlanders.

Een "moeras» met stilstaande poelen ligt op vijftig meter afstand van de "groote markt .... geen huis of ik heb er malaria- of typhuspatienten behandeld.

Maar hoe dit te verbeteren? Ik geloof dat Nero een weldaad zou verrichten als hij zijn euveldaden tegen Rome hier kon herhalen. Van een rooilijn geen sprake; kris en kras door elkaar staan de huizen. Wat al moeilijkheden bij rioleering te overwinnen!

En dit is in de stad. Buiten zou dit onuitvoerbaar blijken.

Hier zullen de leiders en meest beschaafde Minahassers nuttig werk kunnen doen door voor te gaan.

Meer dan vrouwenkiesrecht is in de eerste paar honderd jaar vooral noodig die vrouwen te leeren $o$. a. hare handen te wasschen voor en na het eten, de kinderen oordeelkundig te reinigen en te voeden en zindelijke gerechten te bereiden zonder deze maaltijden te doen besmetten door de vliegen en eigen vieze werkwijze.

Doch hoe weinigen begrijpen het nut van dergelijke zaken, die bovendien niet naar buiten spreken, geen eerzucht bevredigen.

Enkele bevoorrechten willen met sprongen vooruit, doch dit tempo kan een volk niet volgen.

Tuberculose.

Tuberculose ziet men veelvuldig in alle vormen van alle daarvoor vatbare organen.

Lang heeft men gedacht, dat tuberculose in Indië weinig voorkwam. Dit is onjuist gebleken en in de Minahassa is deze ziekte even frequent als elders.

\section{Struma.}

Het bekende kropgezwel der bergbewoners komt in hoogergelegen kampongs in de Minahassa veelvuldig voor. Omtrent de oorsprong dezer ziekte ligt nog veel in het duister. Wel is bekend, dat in sommige bergstreken deze ziekte meer voorkomt dan in naburige evenhoog gelegen, schijnbaar in dezelfde omstandigheden verkeerende, gedeelten des lands.

In Tyrol meent men verband tusschen kropgezwel en drinkwater 
te moeten zoeken, zelfs heeft men daar geconstateerd, dat verplaatsen van een bepaald dorp naar een door een andere bron voorziene streek het percentage kropgezwellen sterk deed dalen. Men zou dus in de Minahassa kunnen beginnen, zoodra daartoe voldoend deskundig personeel aanwezig is, het aantal kroplijders te registreeren en de "vindplaatsen» in kaart te brengen, dan zouden conclusies te trekken zijn omtrent verband met drinkwater en zouden proeven te nemen zijn met verplaatsing van kampongs naar streken (soms zeer naburig) waar deze ziekte minder vaak voorkomt, of men zou het tegenwoordig drinkwater kunnen vervangen door ander. Ook hier dus wacht ontginning op medisch gebied van een onbekend terrein.

Venerische ziekten.

Venerische ziekten zijn zeer verbreid en geven dikwijls vooral bij syphilis, de meest gruwelijke verwoestingen te zien.

Framboesia.

Framboesia komt $\mathrm{niet}$ zoo veelvuldig voor als op Java bijvoorbeeld. Vooral bij deze ziekte kan men met één enkele salversaan injectie schitterende resultaten behalen. Deze ziekte is als volksziekte zéér succesvol te bestrijden, mits de bevolking zich kleine finantieële offers wil getroosten.

\section{Lepra.}

Lepra is niet buitengewoon veelvuldig, doch lang niet zeldzaam. Toevallig, meestal hulp vragende voor andere ziekten, ziet men nu en dan een lepralijder op de polikliniek. Begrijpen de lijders, dat zij lepra hebben, dan ziet men ze niet meer terug, omdat zij zoolang mogelijk den aard van hun lijden willen verbergen, daar zij vreezen uitgesloten te worden van de gemeenschap. Is het eenmaal zoo ver, dan verdwijnen zij in de eenzaamheid, veelal om een ellendigen dood tegemoet te gaan na jaren lang lijden.

$$
\text { Hondsdol heid. }
$$

Hondsdolheid komt het geheele jaar sporadisch voor.

Tientallen patiënten werden door mij naar het Instituut Pasteur gezonden te Weltevreden. Verbod van los laten loopen van honden en onherroepelijk afmaken in dat geval, benevens eene behoorlijke hondenbelasting, zouden al veel verbetering brengen. 
Ten slotte wil ik nog over eene ziekte iets meer zeggen omdat deze voor de Minahassa van groot belang is. Ik bedoel de Ankylostomiasis of mijnwormziekte.

Mijnwormziekte.

Eigenaardig genoeg had ik, toen ik nog geen flauw vermoeden had ooit in de Minahassa geplaatst te zullen worden reeds de verwachting, dat de Inlanders hier veel aan deze ziekte zouden lijden.

In 1913 geplaatst te Paloe, in de wildernissen van Midden Celebes, waar ik ruim twee jaar werkzaam was, hield ik mij onder meer onledig met het onderzoek op mijnwormen bij Inlandsche soldaten, hunne vrouwen en kinderen. Ik vertrouwde mijzelf haast niet toen, buiten elk vermoeden, $82 \%$ bleek mijnwormen te bezitten.

In 1915 te Tjimahi herhaalde ik dit onderzoek in het groote Militair Hospitaal aldaar (waar ik over fijnere onderzoekmethode kon beschikken) bij 200 Menadoneesche soldaten, en vond $95 \%$ gastheer van deze ingewandswormen.

Deze en andere onderzoekingen bleken volkomen gelijke resultaten te geven; eerst toen zijn onze oogen geopend voor het feit hier met een volksziekte te doen te hebben en spoedig daarna is het Leger voorgegaan in systematische bestrijding van dit euvel.

Zonder nu deze ziekte in finesses te gaan beschrijven, wat in een werk voor den beschaafden leek misplaatst zou zijn, wil ik toch op het volgende wijzen ter verdediging van mijne bewering omtrent het groote gewicht van dit lijden.

Een mijnworm is gemiddeld $8 \mathrm{~m} . \mathrm{m}$. groot, en is slechts na uitwasschen van de ontlasting voor het bloote oog waarneembaar. Daar elke vrouwelijke worm 10.000 eieren per dag kan leggen, kan men zóó weinig wormen herbergen, dat ze der aandacht ontgaan van den uitwasscher der ontlasting en dan toch microscopisch tallooze eieren ontdekken. Waar eieren zijn, daar zijn wormen, zoodat het microscopisch onderzoek daarvoor het zekerste bewijs geeft. Dit wormpje heeft de onaangename eigenschap te leven van het darmslijmvlies, waaraan het zich vastzuigt. Weinig wormen doen geringe schade, maar 10.000 , wat nog niet eens veel is voor een lijder, kunnen een belangrijke verwoesting van darmslijmvlies en daardoor verlies van functie 
van dat deel, veroorzaken. Met de ontlasting komen de eieren in den bodem en ontwikkelen zich de larven, die maanden lang blijven leven en zich verspreiden. Komen ze in waterputten dan kunnen ze op die wijze al zeer gemakkelijk in ons lichaam komen; eveneens bij slecht reinigen der handen na grondwerk of tuinarbeid.

Maar, wonderlijk genoeg, dringen zij ook in de huid en dan het eerst in die van de voeten natuurlijk, om na een langen omweg den darm te bereiken.

Herbergt men nu een belangrijk aantal wormen, dan krijgt men het eigenaardige ziektebeeld, dat men mijnwormziekte noemt.

Het voornaamste symptoom is bloedarmoede: bleeke slijmvliezen, lippen en licht rood tandvleesch, verder lusteloosheid, waterzucht van voeten, beenen en handen, een eigenaardig pasteus uiterlijk.

De ernstige gevallen eindigen met den dood, maar wanneer niet ontdekt en verdreven, kan men jaren lang mijnwormen herbergen, zonder eenig ander verschijnsel dan lusteloosheid en bloedarmoede en vage buikklachten.

Juist omdat de klachten in het begin zoo gering zijn is het eenige verschijnsel in het begin gebrek aan werklust.

Van verschillende groote ondernemingen, die hun werkvolk een kuur deden ondergaan kan men hooren dat de werkpraestatie stijgt na een kuur tegen die ziekte bij het werkvolk.

\section{Behandeling.}

De behandeling van deze ziekte is betrekkelijk eenvoudig sinds ontdekt is dat de chenopodiumolie, die bovendien in Indië gewonnen kan worden, daar zulk een schitterend middel tegen is.

Men herhaalt de kuur, die in één dag afgeloopen is, zoolang met vrij groote tusschenpoozen tot wormen en eieren uit de ontlasting verdwenen zijn, wat dus een deskundige moet controleeren.

Men kan een kuur door honderden tegelijk laten doen.

Echter is medisch toezicht daarbij vereischte. Men kan, hoewel dit zeldzaam is, onaangenaame werkingen van het middel ondervinden, die geneeskundige hulp noodig maken.

Omdat de ziekte het eerst bij mijnwerkers is ontdekt dacht men eerst dat de worm aan mijnen gebonden was, vandaar de naam. Het is nu duidelijk, dat mijnwerkers, die in het duister der mijngangen hunne behoefte overal doen, de ziekte al zeer gemakkelijk verbreiden. 
Men moet dus om de ziekte met succes te bestrijden en de infectie kansen voor de Inlanders te verminderen,

$1^{\mathrm{e}}$ Privaten doen aanleggen en het gebruik daarna verplichtend stellen.

$2^{\mathrm{e}}$ Tegengaan het deponeeren van uitwerpselen op de erven of langs de wegen, of in het water, dat voor baden wordt gebruikt.

$3^{\mathrm{e}}$ Ontsmetting van de privaten geregeld doen geschieden.

$4^{\mathrm{e}}$ Aanmoedigen het dragen van schoenen of in elk geval sandalen, al zijn deze ook minder afdoende.

$5^{\mathrm{e}}$ De lijders aan een kuur onderwerpen.

Het is ongeloofelijk zooals het uiterlijk en de levenslust, de werklust terugkomen na een afdoende kuur.

Op ondernemingen deed men die ervaring in ruime mate op. Ik had indertijd een Inlandsch Hospitaal-soldaat tot mijne beschikking, die deze patienten al aan hun voorkomen herkende. Hij sprak van een zieke met een wormengezicht.

Niet buitengewoon is het een magere, bloedarmoede patient in drie maanden 10 Kilo te zien toenemen in gewicht.

Een Inlander, die geen wormen herbergt is een uitzondering op den regel.

Wanneer ik er naar zocht vond ik ze haast altijd bij al mijne patienten in de Minahassa.

Het rondloopen op bloote voeten tehuis en in de tuinen en in de buurt van privaten af te $\mathrm{schaffen}$, het zal een zwaren strijd kosten. Toch mag geen moeite hier te veel zijn.

«Waarom maakt de Minahasser toch zulk een suffen indruk?» vroeg mij een Regeeringscommissaris, die slechts luttele weken hier vertoefde.

Als gevolg van eenzijdige voeding, het gebruik van sagoeweer, reeds in de jeugd aangewend en onzindelijkheid, waardoor elke Inlander mijnwormen herbergt, ziedaar het antwoord.

Beteugeling van de beschreven volksziekten zal de levenskracht van dit van huize uit niet $\mathrm{zwakke}$ ras ten goede komen.

XII.

Indisch-artsen.

De leiders, voorgangers, ziele-herders en doktoren van dit volk zullen hier een ruim arbeidsveld vinden. De Minahassers, 
die Indisch-arts worden, kunnen haast geen mooier werk verlangen dan mede te werken aan de rasverbetering van hun eigen volk.

Belangstelling is er van de Regeering in dit volk zeker altijd overvloedig geweest.

Waar de Minahassers, volgens vele hunner leiders, roepen om méér Gouvernements Indisch-artsen, is dit, ik zou haast zeggen, onbescheiden.

Dit corps is nu eenmaal klein. Percentsgewijze berekend hebben de Minahassers, in vergelijking met andere volken, met den Javaan bijvoorbeeld, al méér doktoren dan hun toekomt.

Een fout is dat men alles van het Gouvernement, en dan liefst gratis, verwacht.

En dit land is een rijk land, met een klappercultuur, die $\mathrm{millioe} n \mathrm{en}$ in het land brengt.

Bijvoorbeeld het welvarende district Tonsea zou best eigen Inlandsche artsen kunnen aanstellen.

Het geld ware daaraan beter besteed dan aan gouden brillenmontuur, gouden *overtrekken» van tanden, Europeesche kleeding en automobielen.

\section{Ziekenfondsen.}

Wanneer men ziekenfondsen stichtte met een contributie van 25 cent per week, wat feitelijk voor niemand in geheel Tonsea een bezwaar zou zijn, dan zouden 4000 menschen een ressort kunnen vormen, dat een eigen geneesheer kon bekostigen.

In 1908 waren er twaalf Minahassische zonen als artsen werkzaam, thans drie. Waarom zijn dezen weggegaan?

Omdat hunne eigen landgenooten hen lieten gaan, door hunne diensten niet te willen betalen.

Dit is nog het gevolg van vroegere toestanden. Een van de eerste contakten met wilde volksstammen krijgt de geneesheer van de expeditie. De zendeling gaf en geeft geneeskundige hulp en de hem, ten gebruike van de behoeftige bevolking verstrekte, geneesmiddelen gratis, bók aan vermogenden.

De bevolking dient te worden opgevoed tot het begrip dat voor geneeskundige hulp en medicijnen behoort betaald te worden door hen die dat vermogen. Nog steeds wordt die hulp beschouwd als een recht van den "bondgenoot der Compenie».

Wanneer de vraag naar meerdere geneeskundige hulp ernstig DI. 80. 
bedoeld is dan bekostige de Minahasser die zelf... $\mathrm{h}$ ij is er toe in staat. Zijn arme landgenooten kan hij er dan mede van laten profiteeren. Ook tot dit begrip van eigen armenzorg moet hij nog worden opgevoed.

Toekomst.

Niets wat een klein volk kan bereiken behoeft op den du ur den Minahasser onbereikbaar te zijn, mits hij ontwikkele de sluimerende goede ras-eigenschappen en slechte invloeden, ook van ziekten, leere onderscheiden en vermijden.

Hij zal hierin van den "Hollander», zijn leermeester, zijn geloofsgenoot, de hulp blijven ontvangen, doch hij verwerpe als ideaal eene oorspronkelijke imitatie, die als alle namaak, eigen karakter mist.

Dat dit gevaar niet denkbeeldig is, bleek mij, waar ik zelfs al gedichten zag van een Minahasser in de Nederlandsche taal. Nog n o o it heeft een kunstenaar in een andere dan zijne moedertaal een kunstwerk geschapen.

Voor evolutie in Westersche cultuur moeten atavistische mogelijkheden bestaan, moet het fundament der beschavingsuitingen Westersch zijn. De Minahasser blijve Oostersch.

Mijne groote belangstelling voor de Minahassa, waaraan Nederland door het trouwe bondgenootschap en de vele militaire diensten zooveel te danken heeft, kon ik niet beter toonen, dan door als medicus, die vier jaren onder hen gewerkt heeft, den weg te wijzen, die ik voor de evolutie van lichaam en geest de beste acht.

Hiermede bewees ik dan tevens, dat wel en wee van dit schoone land en interessante volk mijne aandacht had in de jaren, dat ik hier mocht leven en werken. 